\title{
Adam Narnst
}

\section{The language barrier}

(the) Immanence of a revelation which does not occur is perhaps the aesthetic phenomenon.

Jorge Luis Borges The Wall and The Books

Ain't no party like the Communist Party because the communist party is MANDATORY!

Matt Rea (or maybe some t-shirt he saw once)

This is the third or fourth time someone has asked me to write about Shanghai and the second or third time I've tried to do something about it. I've lived there five times over eight years and I still have no idea where to start. The only stipulation this time is to write something about being an itinerant writer moving between China and Australia. I'm up around the four to five year mark now and I like to tell people it took me six years to write anything about it and the one thing I'm pretty sure of is that anything I write about it is as much my own fiction as any verifiable truth; after five minutes of looking through a couple of the ten or twelve notebooks I've filled I realise that includes the first half of this sentence.

I am now out of excuses, but rather than make you read a bunch of rambling snapshots from the uncontrollable mess of my life just imagine a party you don't know if you want to stay at, but where you never have to understand anyone you don't want to and you never have to worry how you're going to pay for booze.

A Chinese friend from Hong Kong in a black beret comes up to you and speaks in perfect English and hands you a little red book. A notebook that literally looks like the little red books the Chinese children quoted ad-verbatim while they denounced their friends and families and participated in their executions. Mao in profile and 'Serve the people!' blazed across the front. Mao's poem's and quotes placed here and there in Chinese between the blank writing pages, a parting shot on the back, 'But this book is not free. Thankyou!'. You ask him what it means, he says, never mind, and walks off. A ying-yang symbol tells you what it's really saying. You stop for a minute, try to think of something to say. Look across the room as the typical white guy, Chinese girl combo leave seats on the weird faux bird perches that let them overlook the crowd and the bar. You Imagine you are them because you are sick of being the guy with a hole in his heart.

\section{Parrot}

We perch on pipes and planks

The sky is a wedge of blue, black, grey

Cornered by gutters rough with rust and angles

Everyone here has a plan, 


\section{Except you and me, \\ The last real woman, \\ Paying too much, \\ For the last real man.}

My best friends in China are all here. We have a solid system for weeding out the weak through a combination of wordplay, inside jokes, fake racism, misogyny and hyper-profanity. We say things that would get us beat up or stabbed back home but it won't happen here because everyone has something to lose if they can afford to move here and pay rent. An AustralianChinese couple slips through the bubble net because he's built like he was hatched in the Dreamtime from the Rainbow Serpent but never took on human form and Matt can't stop staring at his wife's tits. He starts to ask the same dumb question everyone has to ask when they meet. I stop him after he asks the first one and I tell him I'm going to be a millionaire selling t-shirts for Shanghai expats with a list of answers to that and the next four he's going to ask.

'Adam, four years, Australia, Brisbane etc., International School teacher, writing/philosophy $\mathrm{PhD}$ candidate.' (Tall, heavy build, short dark hair, broad nose, beard)

'Aaron, nine years, Seattle, teacher/business owner/private tutor, English.' (Tall, medium build, short greying hair, bird arms, bird nose, glasses)

'Matt. America! None of your business! We're number one! We're number one! Har-harr-harrr!' (Handsome ageing leprechaun)

For some reason they don't leave straight away. We may be dealing with veterans. Aaron from Seattle can't help but tell them how we all met like we're an old married couple and an exwife.

'I came here not knowing what to expect but knowing if we faced another term of republican presidents I was moving to China or Moscow. And they put me up in this shitty hotel with four other weirdos and I'm like, hey, nice to meet you or whatever and we exchange names and I'm thinking well, I'll never see these guys again. Anyway that was in 2008 and I never left and Matty wasn't there but he was in the same company and he never left. And this asshole Roo keeps hopping in and out but we pretty much been friends ever since.'

They ask if we can speak Chinese, we say 'no', or 'a little' or 'my Chinese is very poor', well enough that they think we're lying or trying to avoid speaking it. I tell them I'm a writer and that I've been going to university for twelve years. I'm still learning English. If I ever learn Chinese I'm not going to do it so I can buy shit from a chemist or negotiate a better deal for some multinational corporate dick. I'm going to spend ten years studying and read the Tang dynasty poets. She asks why we choose to live here if we don't understand it. Aaron says he likes to live in a city that has a vowel named after it.

'In the old days, if you got flaming drunk and someone needed a sailor, they would literally drag you off to the ship while you were passed out and you woke up at sea. You were Shanghai'd. Nowadays we get too drunk and our friends won't let us leave, then they drag us back to the classroom. We're still getting Shanghai'd! Nahhh I had a job at ESPN. I lived a decent life over there, but seriously, this is one of the safest cities in the world. I pass out in the street in America? I'm lucky if I get taken to jail before someone steals my shoes and shoots me 
to death. Here? Worst thing that's gonna' happen is one of my students stands on me because she's too busy playin' on her iPhone.'

They ask us where we live and we say the French Concession instead of Luwan because we don't need these weirdos thinking we are all friends yet. He tells us he lives in Pudong and I correct his pronunciation.

'Pu-Wrong, poo-wrong.'

His wife shakes her head and smiles, like she knew how to party once. 'No. When you first come here you have to live in the French Concession or in Jing-An or at least Puxi. But after five years, you have to live in Pudong.'

West of the s-bend in the Huangpu river the inner-city slowly plies you with drink or drugs, loses you in its maze of close colonial streets, gets you divorced, eats you alive. East of the river is a package deal; all plastic malls, gated communities, Chinese nanny's and million dollar schools. All wide avenues and private gyms on the side; all burning kettle of weird on ours. She's wrong about us, none of us will ever live over there unless we get someone pregnant, or forget that the streets are too wide, the traffic too orderly, the nights lifeless. In the choice between insanity or lobotomy, we choose the ship of fools.

Aaron's getting bored. He sucks down another Memphis cigarette and gazes off like BigBird in a dream sequence. 'Damn hot this summer.'

The white guy smiles, 'We used to have one shitty A/C in Julu lu. It was totally useless, we called it 'The Dog.' We'd have to drag it from room and we'd say 'Come on rex, come on!'

'Yeah man, looking forward to goin' home in a week.' Says Matt, staring at the Chinese woman's chest, looking for nipple creases. 'If my drug dealer doesn't show up soon I'm goin' to have to cancel my subscription.'

I tell them I had a cookie this morning. 'Mate, I was a para-fuckin-lello-gram.'

The Chinese girl spots my new notebook, asks to see it. Scans the first few lines.

'Oh, you are a poet. That is why you are sad.' She says, and lets the book fall to the ground. 'Oh, sorry! Sorry!'

I tell her never mind. I want to ask her how she knows I'm sad but the husband is on the phone.

'Darlin' we gotta' go right now, it's twelve and your mum has been waitin' up with the kids all night. Nice meetin' you guys. Sorry we gotta' rush off.'

'No, problem.' Says Aaron. When they're out of earshot he turns to us, 'Damn, they were boring. That's why I never go out anymore.' story.'

'You're always out, you just don't get let in to nice places.' I laugh. 'I liked the A/C

'I liked her tits,' says Matt.

They cross the party just as she starts to wilt into him with the glaze of one drink too many. I dust off the book and write a few more lines. 
He's as heavy as she is light,

His arms wide as the hips she puts on him,

People move when they stroll through,

Up the stairs and off to bed,

To the faulty dream that sex is.

In The Wall and the Books, Borges writes about Shih Huang Ti (*sic), the emperor who tried to be known as the first Chinese emperor, firstly by burning all the books written before him, and secondly by branding anyone who tried to save books with a hot iron and sending them to a likely death building an 'outrageous wall'. For Borges, ultimately, the Great Wall is literally some kind of language barrier. As Borges says, 'Perhaps the burning of the libraries and the erection of the wall are operations which in some secret way cancel each other.' Or, as he puts it in The Warrior and the Captive, 'The obverse and the reverse of this coin, are for God, the same.'

The party is getting thin and Aaron is going home because he doesn't get in to nice places and Matt is going home because his wife doesn't like it when he does. I am going out because tomorrow I start late and currently I worship at the foot of Leunig's God of loneliness. The boys are teetering on booze legs and slurring about who's custom bicycle is cooler for approximately the twenty-thousandth time. Two Chinese girls walk past arm in hand and stare for a second and ask if they can have a photo in front of the ridiculously stretched longriders, chromed and spoked like chopper-Harley's for man-boys. Matt's is high-barred and banana seated in black; Aaron's low slung and pink gripped in white. The two yanks are yelling over each other arguing about who's is cooler and trying to get the girls to sit on their bikes like it's a promise of a fuck they know they won't get. The girl's giggle, pretend not to understand. I open up a share-bike with an app on my phone and we all roll out with Aaron swaying dangerously through oncoming traffic, abusing taxis like its ever achieved anything. I wave them off and take a detour, see a black guy on a dark corner, buy some 'good stoff' because it helps build the abominable wall between myself and my history, and because I work every goddamn day and this helps me get through it. I burn cash until I'm so high and empty neither fatigue, nor sadness can keep me down. And in these last days of Shanghai I've started writing poems on dancefloors in day-clubs rhyming involuntarily like Leunig's lonely God. I get back as it's closing and the floor is swept and staff filter into seats and drinks but on Sunday they pull a curtain across to veil the dancefloor from the abyss. We're so empty here that the pleasure nearly escapes, but if you look hard enough there are hearts and brains behind the Chinese faces. The music fades like a weekend and the lights rise as I scribble and we walk outside, and against all odds, humans emerge from this dusky shell.

Months later I'm back in Australia, talking to my sister and showing her my notebooks as a shorthand way of explaining what I do with my life to a woman who has three kids and two or three degrees. I've missed her but I'm tired and we both need sleep. She's scanning through story ideas, shopping lists, notes from bar girls, scraps of lesson plans, attempts at poetry, attempts at theory, quotes from giants. Re-reading and tracing lines with thin fingers toned from picking up broken toys and clutching babies to her chest. She asks 'What else would emerge from the shell?' 
I say, 'It's intentionally ambiguous. What do you think would come out?

She smiles 'Zombies!'

'Exactly!' I grin.

'So what exactly is your $\mathrm{PhD}$ about?'

'Creativity and generative violence. That's the short answer.'

'Hmm.' She keeps reading. 'And what inspires you to write?'?'

I try not to cringe, it's something people It's not a stupid question, but I can feel her poking holes in a section of unfinished wall. I shrug, pause, think life, but what I say is a sigh 'Love and suffering'.

Adam Narnst is a writer living between Shanghai, Brisbane and the Gold Coast where he has taught creative writing for many years. He was awarded the Asialink Arts Residency with the Shanghai Writers association in 2015 and his stories and essays shortlisted for several prizes have been published in Australia, China and the USA. 